\title{
ПРАВОВОЕ РЕГУЛИРОВАНИЕ
}

\section{LEGAL REGULATION}

УДК 341.221(5-11+5-12)

DOI dx.doi.org/10.24866/1813-3274/2019-3/53-69

\section{В. Л. Толстых ${ }^{1}$}

Институт философии и права Сибирского отделения Российской академии наук, Новосибирск, Россия

Московский государственный институт международных отношений (Университет) МИД России, Москва, Россия

E-mail:vlt73@mail.ru

\section{ТЕРРИТОРИАЛЬНЫЕ СПОРЫ \\ В ВОСТОЧНОЙ И ЮГО-ВОСТОЧНОЙ АЗИИ: ОСОБЕННОСТИ И ПЕРСПЕКТИВЫ МЕЖДУНАРОДНО-ПРАВОВОГО УРЕГУЛИРОВАНИЯ}

Аннотация. Все территориальные споры в Юго-Восточной и Южной Азии в зависимости от их локализации делятся на четыре группы. В первую входят споры, охватывающие территорию бывшей Британской Индии и связанные с нечёткостью колониальных титулов; во вторую - споры с участием Малайзии, также имеющие колониальный генезис; в третью категорию - споры Японии с её соседями по поводу островов, связанные с нечёткостью послевоенного урегулирования; в четвёртую - споры с участием Китая (помимо споров из первой и третьей групп сюда относится крайне важный спор о принадлежности акватории и сухопутных формирований Южно-Китайского моря). Некоторые из этих споров были разрешены международными судами на основании международного права; к их числу относятся, например, споры о делимитации Бенгальского залива (первая группа). Большинство споров, однако, до сих пор не разрешены, и перспективы правового урегулирования некоторых из них выглядят маловероятными в силу остроты конфликта и

\footnotetext{
${ }^{1}$ Владислав Леонидович Толстых, доктор юридических наук, доцент, Московский государственный институт международных отношений (Университет) МИД России, Москва, Россия; Институт философии и права Сибирского отделения Российской академии наук, Новосибирск, Россия.

Для иитирования: Толстых В. Л. Территориальные споры в Восточной и Юго-Восточной Азии: особенности и перспективы международно-правового урегулирования // Азиатско-Тихоокеанский регион: экономика, политика, право. 2019. № 3. С. 53-69.
}

(C) Толстых В. Л., 2019 
сложности историко-правового контекста. Спор о Южно-Китайском море (ЮКМ) является условно-разрешённым: решение по нему было вынесено в 2016 г. Китай, однако, категорически отказался выполнять его. Отношение России к данным территориальным спорам не должно быть пассивным. В отношении споров из первой группы Россия может попробовать вернуться к своей традиционной функции посредника. Конфликты второй группы не затрагивают её интересов; по отношению к ним она должна соблюдать строгий нейтралитет. Что касается конфликтов третьей группы, то Россия сама является их непосредственным участником и поэтому должна предпринимать усилия, направленные на достижение выгодного для неё решения вопроса о Курильских островах. Наконец, применительно к спору о ЮКМ Россия должна встать на сторону Китая, чьи притязания в отношении данной акватории содержательно близки притязаниям России в отношении Арктики.

Ключевые слова: Юго-Восточная и Южная Азия; международные споры; международное право; международные отношения; международные суды; согласительные средства; территориальные титулы; суверенитет; дипломатия; Конвенция по морскому праву 1982 г.

\author{
Vladislav L. Tolstykh ${ }^{1}$, \\ Institute of Philosophy and Law of the Siberian Branch of the Russian Academy \\ of Sciences, Novosibirsk, Russia \\ Moscow State Institute of International Relations (University), Ministry \\ of Foreign Affairs of Russia, Moscow, Russia \\ E-mail: vlt73@mail.ru
}

\title{
TERRITORIAL DISPUTES IN EAST AND SOUTHEAST ASIA: FEATURES AND PROSPECTS OF INTERNATIONAL LEGAL SETTLEMENT
}

Abstract. All territorial disputes in Southeast and South Asia are divided into four groups depending on their location. The first group includes the disputes covering the territory of the former British India and provoked by the vagueness of colonial titles. The second group includes the disputes involving Malaysia, which also have a colonial genesis. The third group includes the disputes between Japan and its neighbors over the islands provoked by the vagueness of the post-war settlement. The fourth group includes

\footnotetext{
${ }^{1}$ Vladislav L. Tolstykh, Doctor of Law, Associate Professor, Institute of Philosophy and Law of the Siberian Branch of the Russian Academy of Sciences, Novosibirsk, Russia; Moscow State Institute of International Relations (University), Ministry of Foreign Affairs of Russia, Moscow, Russia.

For citing: Tolstykh V. L. Territorial disputes in East and Southeast Asia: features and prospects of international legal settlement // PACIFIC RIM: Economics, Politics, Law. 2019. № 3. P. 53-69.
} 
the disputes involving China, - in addition to the disputes from the first and third groups, this includes an extremely important debate about the ownership of water spaces and land formations of the South China Sea. Some of these disputes have been resolved by international courts under international law; these include, for example, the disputes over the delimitation of the Bay of Bengal (first group). Most disputes, however, are still not resolved and the prospects for legal settlement of some of them seem unlikely due to the severity of the conflict and the complexity of historical and legal contexts. The dispute over the South China Sea is conditionally resolved: a judgment was rendered in 2016, China, however, categorically refused to comply with it. Russia's attitude to these territorial disputes should not be passive. As for the disputes from the first group, Russia may try to return to its traditional mediator function. The conflicts of the second group do not affect its interests, therefore it must observe a strict neutrality in relation to them. As for the conflicts of the third group, Russia is directly involved in them and therefore should make efforts to achieve an advantageous solution of the Kuril Islands case. Finally, in relation to the South China Sea dispute Russia should support China's position which is substantially close to Russia's claims in relation to the Arctic.

Key words: Southeast and South Asia; international disputes; international law; international relations; international courts; conciliation; territorial titles; sovereignty; diplomacy; Convention on the Law of the Sea 1982.

1. Территориальные споры в Юго-Восточной и Южной Азии представляют особый интерес для российской доктрины международного права: во-первых, в некоторые из них Россия вовлечена прямо; во-вторых, разрешение некоторых из них в силу своего прецедентного характера может повлиять на разрешение споров в других регионах, в том числе с участием России; в-третьих, данные споры часто имеют сложный контекст и предполагают применение сразу нескольких групп норм, применимых к территориальным спорам: норм, регулирующих постколониальное устройство; норм, основанных на эффективности; и, наконец, специальных договорных норм. Российская доктрина традиционно уделяет большое внимание российско-японскому спору о принадлежности Курильских островов $[1$, 2]; в зарубежной доктрине, помимо такого рода специальных работ, имеются общие обзорные исследования $[5,6,7]$.

Все территориальные споры в Юго-Восточной и Южной Азии в зависимости от их локализации делятся на четыре группы. В первую входят споры, охватывающие территорию бывшей Британской Индии и связанные с нечёткостью колониальных титулов. Они, как правило, носят острый политический (геополитический) характер; затрагивают интересы третьих государств, в том числе сверхдержав; 
предполагают анализ не только территориальных титулов, но и притязаний на самоопределение; провоцируют постоянное напряжение и чреваты вооруженными конфликтами. Их судебное разрешение, как правило, маловероятно; более предпочтительным выглядит использование согласительных механизмов. Исключение составляют несколько споров по поводу делимитации Индийского океана. Во вторую входят споры с участием Малайзии, также имеющие колониальный генезис. Данные споры обострились в связи с развитием морского права, которое в настоящее время позволяет государствам претендовать на огромные морские пространства вокруг их сухопутных территорий, - как результат, небольшие морские формирования, до недавнего времени не вызывавшие интереса у прибрежных государств, приобрели большое экономическое значение. Как показывает практика, данные споры вполне могут быть разрешены на основании международного права. В третью категорию входят споры Японии с её соседями по поводу островов, связанные с нечёткостью послевоенного урегулирования. Данные споры имеют одновременно символическое и экономическое значение. Теоретически они вполне могут быть урегулированы на основании международного права, однако стратегическое значение данного региона и связанность самих споров создают труднопреодолимое препятствие. В четвёртую категорию входят споры с участием Китая, - помимо споров из первой и третьей групп сюда относится крайне важный спор о принадлежности акватории и сухопутных формирований Южно-Китайского моря. Этот спор относится к разряду условно-разрешённых: 12 июля 2016 г. по нему было вынесено арбитражное решение, которое Китай категорически отказался исполнять.

2. Наиболее важными спорами из первой группы являются следующие.

1) В августе 1947 г. был осуществлён раздел Британской Индии между Индией и Пакистаном; бывшие княжества должны были самостоятельно сделать свой политический выбор. Махараджей княжества Джамму и Каммир был индуист Хари Сингх, 77 \% населения составляли мусульмане. Махараджа стремился к независимости, однако население предпочитало союз с Пакистаном. Осенью 1947 г. оно восстало против махараджи; ему на помощь пришли пуштунские племена с территории Пакистана. В конце октября на западе княжества было создано государство Азад Кашмир (Свободный Кашмир), которое присоединилось к Пакистану. Махараджа заявил о вхождении княжества в состав Индии и запросил у неё военную помощь. После этого разразилась первая индо-пакистанская война (1947-1948), по итогам которой была зафиксирована Линия прекращения огня, разделившая Кашмир на две части: Пакистану отошла территория площадью 77,5 тыс. кв. км (почти половина княжества). Данная территория делится на две части - Северные территории и собственно Азад Кашмир, имеющий статус ассоциированного государства. Благодаря контролю над ней Пакистан имеет общую границу со своим стратегиче- 
Толстых В. Л. Территориальные споры в Восточной и Юго-Восточной Азии: особенности и перспективы международно-правового урегулирования

ским союзником Китаем. В 1963 г. Пакистан и Китай подписали договор о границе, по которому долина Шаксгама/Кырчинбулака (5,18 тыс. кв. км.) была отнесена к Китаю; по мнению Индии, эта территория является индийской. На раннем этапе конфликта $\mathrm{OOH}$ призывала к проведению референдума; это предложение не было реализовано, т.к. Индия считает Кашмир своей законной территорией. Последняя эскалация конфликта имела место в феврале 2019 г.

2) Регион Аксайчин (42,7 тыс. кв. км) относится к Тибетскому плато. Некогда он был частью королевства Ладахк, в середине XIX в. был захвачен Кашмиром, а после победы британцев над сикхами отошел британцам. Граница Британской Индии с Китаем не была определена, и в 1865 г. британский чиновник У. Джонсон предложил линию, относившую Аксайчин к Кашмиру; Китай не был осведомлён об этой линии, так как не контролировал Синьцзян, где происходило Дунганское восстание. В 1878 г. Китай вновь отвоевал Синьцзян, а в 1892 г. установил пограничные знаки на перевале Каракорум. В 1899 г. Великобритания предложила использовать линию Маккарти-Макдональда, проведённую вдоль хребта Каракорум, являвшегося естественной границей (среди прочего, она стремилась помешать российской экспансии). Согласно этой линии Аксайчин относился к Китаю. Китайские власти не ответили на это предложение. Некоторое время Великобритания использовала линию Маккарти-Макдональда, однако после Синьхайской революции 1911 г., приведшей к коллапсу центральной власти в Китае, стала использовать линию Джонсона. После приобретения Индией независимости её правительство также стало использовать линию Джонсона. В 50-х гг. КНР построила дорогу между Синьцзяном и западным Тибетом. 179 км дороги проходят к югу от линии Джонсона, через Аксайчин, который более доступен для китайцев, чем для индийцев, находящихся на другой стороне хребта. Это привело к Индо-Китайской войне 1962 г. Китай считает, что граница никогда не была делимитирована, а единственной предложенной ему границей была линия Маккарти-Макдональда; кроме того, Аксайчин уже находится под его юрисдикцией.

3) Регион Аруначал-Прадеш (84 тыс. кв. км) находится на северо-востоке Индии. В 1913-1914 г. в г. Шимла прошли переговоры о статусе Тибета между представителями Индии, Тибета и Китая. Британский губернатор Мак-Магон предложил разделить Тибет на Внутренний, под юрисдикцией Китая, и Внешний, пользующийся автономией под управлением Далай-ламы. Он также провел границу между Тибетом и Британской Индией (линия Мак-Магона), относящую АруначалПрадеш к Индии; эта граница обсуждалась представителями Великобритании и Тибета приватно, в отсутствие китайского представителя, и была нанесена на карту, приложенную к проекту Соглашения. Китай, считавший Тибет своей территорией (это подтверждалось приложением к Соглашению), не согласился с китайскотибетской границей и отказался от договора в целом (в том числе и от индо- 
тибетской границы). После этого представители Великобритании и Тибета лишили Китай привилегий по Соглашению и подписали его как двустороннее. Соглашение было отвергнуто Индией как несовместимое с Англо-Российской Конвенцией 1907 г., и линия Мак-Магона не приобрела обязательного характера. Конвенция 1907 г. была прекращена Россией и Великобританией в 1921 г., а в 30-х гг. Великобритания начала ссылаться на линию Мак-Магона как на официальную границу и признавать действительность Соглашения 1914 г. Округ Таванг остался под тибетским управлением, но власти Тибета не препятствовали Великобритании действовать в других секторах. В 1947 г. Индия стала независимой и объявила линию МакМагона индокитайской границей, в 1950-1951 г. она установила контроль над Тавангом. В 1950 г. КНР захватила Тибет, после чего оспорила линию Мак-Магона, заявив, что Тибет не мог самостоятельно заключать договоры о границах. КНР продолжает выдвигать претензии на регион, рассматривая его как Южный Тибет.

4) Ледник Сиачен расположен в горах Каракорум и начинается там, где заканчивается Линия контроля (прекращения огня) между Индией и Пакистаном. Американские и пакистанские карты 70-80-х гг. относят его к Пакистану, что воспринимается Индией как картографическая ошибка и нарушение Соглашения 1949 г. (Карачи) и Соглашения 1972 г. (Шимла). Соглашение 1949 г. проводит линию прекращения огня до точки NJ9842, от которой линия границы должна идти «на север к ледникам». По мнению Пакистана, она должна идти до перевала Каракорум; по мнению Индии - вдоль хребта Сальторо (по линии водораздела), огибая ледник с запада. В 1984 г. Индия провела операцию Meghdoot («Облачный посланник») и установила контроль над районом ледника, приобретя около 3 тыс. кв. км. В 1984-1899 гг. имели место частые перестрелки между индийскими и пакистанскими военными; кроме того, несколько сотен солдат с каждой стороны погибли из-за воздействия суровых природных условий.

5) Лиман Сэр Крик (Sir Creek) расположен на границе Индии (штат Гуджарат) и Пакистана (провинция Синд). Пакистан претендует на весь лиман, ссылаясь на Резолюцию 1914 г., подписанную Правительством Синда и махараджей Кача (Гуджарат) и устанавливающую границу по восточному берегу. Индия настаивает на границе по середине, указанной на карте 1925 г. и соответствующей обычному праву. Пакистан утверждает, что этот обычай применяется только к рекам; Индия в ответ ссылается на несколько прецедентов его использования в лиманах. После 1969 г. было проведено несколько раундов переговоров, не принесших результата. В 1999 г. индийский МиГ-21 сбил в этом районе пакистанский разведывательный самолет; стороны регулярно арестовывают рыбаков другой стороны за незаконное пересечение границы. В регионе имеются большие запасы нефти и газа.

3. Два спора из первой группы, касающихся делимитации Бенгальского залива, были разрешены судебным путём. Данные споры имели исключительно экономи- 
Толстых В. Л. Территориальные споры в Восточной и Юго-Восточной Азии: особенности и перспективы международно-правового урегулирования

ческое значение; одной из сторон в обоих случаях был Бангладеш; правовой режим споров не выходил за пределы ст. ст. 15, 74 и 83 Конвенции по морскому праву 1982 г.

1) 14 марта 2012 г. Международный трибунал по морскому праву ${ }^{1}$ делимитировал границу между Бангладеш и Мьянмой. При делимитации территориального моря Трибунал применил линию эквидистанции и не признал особым обстоятельством остров св. Мартина (ст. 15). При делимитации исключительной экономической зоны и континентального шельфа он применил метод эквидистанции/относимых обстоятельств; счёл относимым обстоятельством вогнутость берега Бангладеш и не счёл таковым наличие острова св. Мартина, а также геологические особенности дна (ст. 74, 83). Длина относимого побережья Бангладеш составляет 431 км, а побережья Мьянмы - 587 км $(1: 1,42) ; 111,6$ тыс. кв. км отошло Бангладеш, 171,8 - Мьянме $(1: 1,54)$. Это соотношение не образует значительной диспропорции.

2) 7 июля 2014 г. арбитражный суд делимитировал границу между Бангладеш и Индией. При делимитации ТМ суд применил линию эквидистанции (ст. 15) и не признал особыми обстоятельствами нестабильность и вогнутость берега, отметив, что общая конфигурация залива не должна влиять на делимитацию узкого пояса ТМ. При делимитации ИЭЗ и КШ он применил метод эквидистанции/относимых обстоятельств (ст. 74, 83). Он не признал относимым обстоятельством нестабильность берега Бангладеш (относимыми являются только геофизические условия), а также заинтересованность его населения в рыбном промысле (Бангладеш не доказал свою зависимость от данного промысла). Он, однако, признал таковым вогнутость берега Бангладеш. Длина берега Бангладеш составляет 418,6 км; Индии 803,7 (1:1,92); 106,6 тыс. кв. км отошло Бангладеш, 300 - Индии $(1: 2,81)$. Это соотношение не образует значительной диспропорции.

4. Три спора из второй группы были разрешены на основе международного права; в двух случаях стороны использовали судебные механизмы, в одном - согласительные.

1) 17 декабря 2002 г. МС ООН разрешил спор о принадлежности островов ПулауЛигитан и Пулау-Сипадан, расположенных в море Сулавеси. Суд не смог определить титул на основании Договора между Великобританией и Нидерландами 1891 г. или актов правопреемства и в этой связи применил принцип эффективности. Индонезия ссылалась на патрулирование района островов кораблями голландского королевского флота, действия индонезийского флота и деятельность индонезийских рыбаков. Малайзия же ссылалась на регулирование ловли черепах и сбора черепашьих яиц на ост-

\footnotetext{
${ }^{1}$ Здесь и далее используются следующие сокращения: МТМП - Международный трибунал по морскому праву; МС ООН - Международный суд ООН; ВВ - внутренние воды; ТМ - территориальное море; ИЭЗ - исключительная экономическая зона; КШ - континентальный шельф; ОМ - открытое море.
} 
ровах; создание на острове Сипадан в 1933 г. птичьего заповедника; строительство на островах маяков, обслуживаемых малазийскими властями. Суд отметил, что в отношении небольших островов действия по осуществлению контроля, как правило, незначительны. Ни одно из действий Индонезии не имеет законодательного или административного характера; из факта патрулирования не следовало, что Индонезия рассматривала острова как свои; деятельность же рыбаков не может рассматриваться как исходящая от государства. Действия Малайзии, наоборот, могут быть расценены как предполагающие притязания на суверенитет. Количество этих действий - невелико, но они разнообразны по содержанию и охватывают значительный период времени. Ни Индонезия, ни Нидерланды не протестовали против них во время их осуществления. Таким образом, острова принадлежат Малайзии.

2) 23 мая 2008 г. МС ООН вынес решение о принадлежности трёх образований Сингапурского пролива: Педра Бранка (гранитный остров), Миддл Рокс (несколько скал) и Сауф Ледж (обнажающееся при отливе возвышение). В 1867 г. Сингапур стал британской колонией. В 1885 г. Султанат Джохор (Малайзия) стал британским протекторатом. Малайская федерация приобрела независимость в 1957 г.; в 1963 г. в результате объединения её и нескольких бывших колоний, в том числе Сингапура, была создана Малайзия. В 1965 г. Сингапур вышел из состава Малайзии и стал независимым государством. Суд установил, что владения Султаната Джохор охватывали все острова пролива, включая Педра Бранка. Он, однако, учёл переписку 1953 г.: в письме от 12 июня 1953 г. власти Сингапура запросили у властей Джохора сведения о Педра Бранка; в письме от 21 сентября 1953 г. власти Джохора ответили, что не претендуют на этот остров. Ответ Джохора позволял властям Сингапура рассматривать остров как британское владение. Поведение Сингапура после 1953 г. является поведением à titre de souverain (расследование кораблекрушений, регламентирование исследований, изучение возможности увеличения острова). Малайзия не отреагировала на установление на Педра Бранка флага Сингапура и на своих картах обозначала остров как принадлежащий Сингапуру. В итоге Суд счёл, что Педра Бранка принадлежит Сингапуру. Факты, определяющие суверенитет Сингапура над Педра Бранка, однако, не относятся к Миддл Рокс и Сауф Ледж. Следовательно, Малайзия как преемник Джохора должна рассматриваться как сохранившая изначальный титул на Миддл Рокс. В месте нахождения Сауф Ледж территориальные воды континентальной Малайзии, Педра Бранка и Миддл Рокс перекрывают друг друга. В этой связи суверенитет над Сауф Ледж принадлежит тому государству, в чьих территориальных водах он находится.

3) Малайзия утверждала, что работы Сингапура по расширению его естественной территории нарушают Конвенцию 1982 г. Применительно к работам на острове Пулау Теконг она утверждала, что эти работы угрожают судоходству, окружающей среде и образу жизни местных рыбаков; применительно к строительству поста на 
Толстых В. Л. Территориальные споры в Восточной и Юго-Восточной Азии: особенности и перспективы международно-правового урегулирования

острове Туас - что Сингапур посягает на её ТМ в районе Point 20 sliver (выступ ТМ Малайзии в сторону Сингапура, обозначенный на её карте 1979 г.). Сингапур не признаёт эту границу и считает, что Point 20 sliver не находится под суверенитетом Малайзии. В 2003 г. Малайзия запросила у МТМП временные меры; в Определении от 8 октября 2003 г. Трибунал, однако, счёл, что применительно к деятельности на острове Туас Малайзия не доказала срочность (риск непоправимого ущерба). Применительно к работам на Пулау Теконге Суд постановил, что стороны должны создать группу экспертов, которая подготовит доклад о последствиях деятельности Сингапура и предложит меры для предотвращения негативных последствий. Через 13 месяцев эксперты подготовили доклад, на основе которого стороны заключили Соглашение от 26 апреля 2005 г.: Сингапур должен был заплатить Малайзии 374 тыс. ринггитов (90 тыс. долл.) в качестве компенсации потерь рыбаков (каждый рыбак получил 5.200 ринггитов); он также изменил модель береговой линии и заверил Малайзию, что его работы не повлияют на судоходство. В отношении Point 20 sliver стороны ещё не достигли урегулирования.

5. Среди неурегулированных споров из второй группы следует отметить спор о принадлежности участка Амбалат в море Сулавеси и спор о принадлежности Северного Борнео.

1) Участок Амбалат (Ambalat) примыкает к восточному берегу Борнео. В 1979 г. Малайзия опубликовала карты ТМ и КШ, в соответствии с которыми Амбалат был включён в её воды (морская граница шла от восточного пункта сухопутной границы в юго-восточном направлении). Индонезия опротестовала эту границу. С 1959 г. Индонезия претендовала на острова Сипадан и Лигитан, которые в 1979 г. Малайзия использовала в качестве базовых точек архипелажных линий, таким образом, весь участок Абмалат оказался в её ВВ. Индонезия ссылалась на Договоры между Великобританией и Нидерландами 1891, 1915, 1928, 1930 гг., относившие Амбалат к её водам. В 2002 г. МС ООН счёл, что спорные острова принадлежат Малайзии. Индонезия признала, что острова имеют собственное ТМ, но заявила, что часть Амбалата относится к её КШ. При этом она использует в качестве базовой точки скалу Takat Unarang, находящуюся на расстоянии 10 морских миль от линии отлива (нормальных базовых линий), - это влечёт смещение линии эквидистанции в сторону Малайзии. Оба государства предоставили концессии на добычу нефти на спорном участке.

2) Северное Борнео (Sabah) является предметом спора между Малайзией и Филиппинами. Последние считают себя преемником Султаната Сулу, который в 1878 г. отдал эту территорию британскому синдикату в аренду за 5 тыс. малайских долларов в год. В 1888 г. Северное Борнео стало протекторатом Великобритании, в 1890 г. - её колонией; в 1963 г. получило самоуправление и вошло в состав Малайской Федерации. Малайзия считает Соглашение 1878 г. цессией и ссылается на ре- 
ализацию в 1963 г. права на самоопределение. Кроме того, в 60-е гг. Миссия ООН в Борнео провела консультации с населением и представила доклад, согласно которому большинство жителей желают присоединиться к Малайзии (Индонезия и Филиппины, однако, отвергли выводы комиссии). Соглашение 1878 г., составленное на малайском языке, использует термин pajakan, который был переведён испанскими лингвистами в 1878 г. и американскими антропологами в 1946 г. как arrendamiento или lease. Британцы, однако, ссылаются на переводы 1908 г. и 1924 г., согласно которым это слово переводится как предоставление и уступка; кроме того, в Соглашении говорится о передаче навсегда (selama-lama).

6. К третьей категории относятся три спора с участием Японии, имеющие общий нормативный контекст.

1) Симодский трактат 1855 г. зафиксировал российско-японскую границу между островами Уруп и Итуруп, подтвердив тем самым права Японии на Итуруп, Кунашир, Шикотан и острова Малой Курильской гряды (Хабомаи). По СанктПетербургскому договору 1875 г. Россия уступила Японии все Курильские острова, а Япония России - права на Сахалин. По Портсмутскому договору 1905 г. Россия уступила Японии южную часть Сахалина. В 1945 г. СССР, США и Великобритания заключили Крымское соглашение по вопросам Дальнего Востока, по которому СССР согласился вступить в войну с Японией при условии передачи ему южной части Сахалина и Курильских островов. В Потсдамской декларации 1945 г. союзники заявили, что «японский суверенитет будет ограничен островами Хонсю, Хоккайдо, Кюсю, Сикоку и теми менее крупными островами, которые мы укажем». Курилы, не указанные в Декларации, к осени 1945 г. были заняты СССР. В СанФранцисском мирном договоре 1951 г. Япония отказалась от прав на Курилы и южную часть Сахалина (ст. 2c); СССР, однако, не участвовал в этом договоре. В 1956 г. СССР и Япония приняли Совместную декларацию о прекращении состояния войны и восстановлении дипломатических отношений. П. 9 Декларации гласит: «СССР, идя навстречу пожеланиям Японии и учитывая интересы японского государства, соглашается на передачу Японии островов Хабомаи и острова Сикотан с тем, однако, что фактическая передача этих островов Японии будет произведена после заключения Мирного Договора между СССР и Японией». Мирный договор не был заключен, и в 1960 г. СССР отказался от передачи островов, заявив, что это приведёт к увеличению территории, используемой силами США. С тех пор Япония периодически заявляет о своих правах на острова и опротестовывает действия России, связанные с управлением ими.

2) Острова Лианкур (кор. - Токто; яn. - Такэсима) находятся в западной части Японского моря, недалеко от корейского архипелага Уллындо, и контролируются Южной Кореей. Исторические источники указывают, что в VI в. острова вошли в состав Силлы (современная Корея) и впоследствии использовались корейскими 
Толстых В. Л. Территориальные споры в Восточной и Юго-Восточной Азии: особенности и перспективы международно-правового урегулирования

рыбаками; Япония, однако, полагает, что эти ссылки относятся к другим островам. Япония долгое время признавала принадлежность островов Корее, однако в 1905 г. включила их в состав префектуры Симанэ. После победы над Японией власти США приостановили юрисдикцию Японии над многими островами, в том числе над островами Лианкур (Директива № 677 от 29 января 1946 г.). Директива, однако, «не указывала на политику союзников в отношении окончательного определения [статуса] менее крупных островов» и, таким образом, не определяла принадлежность Лианкур. Сан-Францисский договор 1951 г. закрепил отказ Японии от всех прав и претензий на Корею, включая острова Квельпарт, порт Гамильтон и Дагелет; Лианкур при этом не упоминались (ст. 2). В 1952 г. Южная Корея объявила о своем суверенитете над Лианкур. В 1954 г. и 2012 г. Япония предлагала передать спор в MC OОН, на что Южная Корея ответила отказом. В 1965 г. стороны заключили Базовый договор об отношениях, в котором признали наличие спора об островах. Время от времени Япония напоминает о своих претензиях и делает попытки проявить свою юрисдикцию в районе.

3) Острова Сенкаку находятся в Восточно-Китайском море. В январе 1895 г. Япония заняла острова и включила их в свой состав, посчитав, что они являются terra nullius. Симоносекский договор 1895 г. оформил окончание японо-китайской войны и передал Японии остров Тайвань и зависимые от него острова, но не указал, о каких именно островах идет речь. Сан-Францисский договор 1951 г. лишил Японию Тайваня и зависимых островов (ст. 2) и аннулировал Симоносекский договор. По мнению Китая и Тайваня, это означало отказ в том числе от Сенкаку. Ст. 3 Договора передала управление островами Рюкю США; Япония утверждает, что одновременно были переданы права управления Сенкаку. В 1972 г. США передали Рюкю и Сенкаку Японии. Китай ссылается на то, что острова были открыты китайцами, стали китайской территорией в XVI в., использовались Китаем для защиты от японских пиратов, обозначены как китайские на японской карте XVIII в.; были незаконно захвачены Японией в 1895 г.; в Потсдамской декларации 1945 г. Япония отказалась от заморских территорий; Китай опротестовал Соглашение о возвращении Окинавы 1971 г. Япония утверждает, что Китай не доказал контроль над Сенкаку до 1895 г.; она установила контроль над островами в 1895 г.; не отказалась от них на основании ст. 2 Договора 1951 г.; с 1972 г. осуществляет управление ими (взимание налогов, борьба с незаконным рыболовством, управление землей, проведение исследований и др.); Китай предъявил претензии только в 1971 г., после того, как в районе были обнаружены запасы нефти и газа; острова находятся на расстоянии 330 км от китайского берега. Спор о принадлежности Сенкаку рассматривается как потенциальный casus belli.

7. В четвертую группу входит крайне важный и сложный спор о ЮжноКитайском море. 
В 2013 г. Филиппины начали процесс против Китая. Последний отказался участвовать в процессе, посчитав, что спор касался суверенитета над морскими образованиями (не регулируемого Конвенцией 1982 г.) и делимитации (исключенной Китаем из юрисдикции суда) ${ }^{*}$. В этой связи один арбитр был назначен Филиппинами, а четыре - Председателем МТМП. 29 октября 2015 г. Суд вынес Решение по юрисдикции, в котором счёл, что дело не связано с суверенитетом и не затрагивает делимитацию. Морская граница может быть делимитирована только между государствами с пересекающимися притязаниями; спор о притязаниях может существовать без пересечения, если государство претендует на районы в области, которую другие государства считают частью ОМ.

12 июля 2016 г. Суд вынес решение по существу. В Требованиях № 1 и № 2 Филиппины просили Суд признать, что Китай не обладает в ЮКМ историческими правами, в том числе в пределах Линии девяти штрихов (Л9Ш). Данная линия ограничивает большую часть ЮКМ; Китай упоминал её в дипломатической переписке и публичных заявлениях. Суд отметил, что большая часть области Л9Ш покрывается претензией Китая на ИЭЗ и КШ, отмеряемые от островов Спратли, которые Китай считает своими. Однако в некоторых случаях Китай претендовал на права, не предусмотренные Конвенцией, например, запрещал летнее рыболовство во всем ЮКМ. Одновременно он заявлял, что уважает свободы судоходства и пролетов в ЮКМ. Поскольку Конвенция не распространяет эти свободы (за исключением мирного прохода) на ТМ и ВВ, это свидетельствует о том, что Китай не рассматривает область Л9Ш как своё ТМ или свои ВВ. Кроме того, Китай не устанавливал бы исходные линии для ТМ, огибающие Хайнань и Парасельские острова (а он сделал это), если бы воды вблизи этих островов уже образовывали часть его ТМ или ВВ на основании исторических титулов. В итоге Суд счёл, что Китай претендует на ресурсы в области Л9Ш, но не считает её частью своего ТМ или своих ВВ.

Далее Суд определил, покрывается ли спор исключением, касающимся «исторических правооснований» (ст. 298 (1a,i)). Он указал: «Термин «исторические права» является общим по своей природе и может описывать любые права, принадлежащие государству, которые, как правило, не возникают в соответствии с общими нормами международного права в отсутствие конкретных исторических обстоятельств. Исторические права могут включать суверенитет, но могут также включать более ограниченные права... «Историческое правооснование», наоборот, используется специально для обозначения исторического суверенитета над землей или морскими районами» (пар. 225). Таким образом, ст. 298 (1a,i) не исключает

\footnotetext{
* Ст. 298 Конвенции гласит: «...Государство ... может в письменной форме заявить, что оно не принимает одну или несколько процедур, предусмотренных в Разделе 2 , в отношении одной или более нижеследующих категорий споров: $a$ ) i) споров, связанных с толкованием или применением статей 15 , 74 и 83, касающихся делимитации морских границ, или споров, связанных с историческими заливами или правооснованиями». Китай сделал соответствующее заявление в 2006 г.
} 
Толстых В. Л. Территориальные споры в Восточной и Юго-Восточной Азии: особенности и перспективы международно-правового урегулирования

юрисдикцию Суда в отношении притязаний на исторические права, не подпадающие под категорию «суверенитет». Претензия Китая на исторические права в отношении ресурсов ЮКМ в области Л9Ш совместима с Конвенцией в той мере, в какой она вытекает из юрисдикции над ИЭЗ и КШ, и несовместима с ней в той меpe, в какой выходит за пределы этих районов. Это ясно следует из Конвенции, регулирующей права других государств в ИЭЗ и КШ и не предусматривающей возможности установления в этих районах исторических прав (пар. 261-262). Долгое время судоходство, торговля и рыболовство Китая за пределами ТМ реализовывали свободы ОМ. Эту деятельность могли осуществлять все страны, поэтому она не может обосновывать исторические права. Ратифицировав Конвенцию, Китай отказался от использования свобод ОМ в чужой ИЭЗ. В то же время он приобрёл больший контроль над районами, создаваемыми его побережьем. Таким образом, его притязания в области Л9Ш не могут выходить за пределы его прав по Конвенции.

В Требованиях № 3 - № 7 Филиппины просили определить характер десяти образований в ЮКМ; от этого зависел вопрос о том, имеют ли они собственные ИЭЗ и КШ. Конвенция упоминает осыхающие при отливе возвышения (ст. $\left.13^{*}\right)$, скалы и острова (ст. 121**); лишь последние имеют ИЭЗ и КШ. Суд указал, что характер образования должен определяться с учётом его естественного состояния. De jure человеческие модификации не могут превратить дно в возвышение, а последнее в остров (пар. 305). Термин «жизнь человека» предполагает поселение на образовании сообщества людей, для которых оно является домом и на котором они могут оставаться. «Хозяйственная деятельность» должна ориентироваться на само образование, а не только на его воды или морское дно. Деятельность, полностью зависящая от внешних ресурсов или состоящая в добыче ресурсов без вовлечения местного населения, не имеет необходимой связи с образованием. Ст. 121 (3) говорит о пригодности образования для проживания, а не о его населённости в настоящее время или в прошлом. Доказательства физических условий обычно позволяют определить пригодность, в пограничных случаях они, однако, недостаточны. В таких случаях доказательством является историческое использование. Образование, которое никогда не было населено, скорее всего, не пригодно для поддержания жизни человека. И наоборот, если на нем живут или жили люди, нужно определить, стала ли такая жизнь возможной лишь благодаря внешней поддержке. Если внеш-

\footnotetext{
* «1. Осыхающее при отливе возвышение представляет собой естественно образованное пространство суши, окруженное водой, которое находится выше уровня воды при отливе, но покрывается водой при приливе...».

«1. Остров представляет собой естественно образованное пространство суши, окружённое водой, которое находится выше уровня воды при приливе. 2. За исключением, предусмотренным в п. 3, ТМ, прилежащая зона, ИЭЗ и КШ острова определяются в соответствии с положениями настоящей Конвенции, применимыми к другим сухопутным территориям. 3. Скалы, которые не пригодны для поддержания жизни человека или для самостоятельной хозяйственной деятельности, не имеют ни ИЭЗ, ни КШ».
} 
няя поддержка образует необходимое условие для заселения, то жизнь человека не поддерживается самим образованием. В этой связи официальное или военное население, обслуживаемое извне, не свидетельствует о пригодности для поддержания жизни (пар. 540-551). Применив эти критерии, Суд счёл, что ни одно спорное образование не является островом. Китай осуществил на них строительные работы, но его присутствие зависит от внешних поставок; доказательства человеческой активности до 1988 г. отсутствуют. Таким образом, они не пригодны для поддержания жизни человека или самостоятельной хозяйственной деятельности и не имеют собственных ИЭЗ и КШ.

Выводы Суда выглядят спорными. Bo-nервых, Суд счёл, что спор не касается делимитации, т.к. не предполагает пересечения притязаний (и потому не подпадает под заявление Китая 2006 г.). На второй стадии он решил, что возвышения ЮКМ не являются островами и потому не могут быть присвоены и не создают прав на ИЭЗ и КШ. Этот вывод, однако, прямо касается делимитации: фактически Суд установил, что морские районы Китая простираются не там, где предполагал Китай, а в другом месте, и именно поэтому не пересекаются с морскими районами Филиппин. Решающее значение при квалификации спора как касающегося делимитации имеет не пересечение притязаний, а существование спорной границы.

Bo-вторых, Суд счёл, что спор не связан с «историческими правооснованиями» и привязал этот термин к территориальному суверенитету; Китай же, по мнению Суда, настаивал на иных правах. То, что термин «правооснование» (title) часто используется в контексте претензий на суверенитет, не означает, что он не может быть использован в ином контексте. Кроме того, в Решении по делу об охраняемой зоне Чагоса (Маврикий против Великобритании) от 18 марта 2015 г. арбитражный суд указал, что споры о суверенитете в принципе исключены из сферы действия Конвенции (и, следовательно, не могут исключаться из юрисдикции суда на основании ст. 298(a)(i)); на этом основании он отказался рассматривать тезис Маврикия о том, что Великобритания не является прибрежным государством.

$B$-третьих, вывод Суда, согласно которому Китай не претендовал на суверенитет, выглядит необоснованным: Суд сослался на то, что Китай уважал свободу судоходства, которая обычно не признается в районах, находящихся под суверенитетом. Однако предоставление иностранным государствам больших прав, чем те, которые предусмотрены Конвенцией, не запрещено; в Решении по делу о континентальном шельфе от 24 февраля 1982 г. МС ООН указал, что общее право предусматривает не единый режим для «исторических вод», а особый режим для каждого конкретного случая «исторических вод» (пар. 100).

$B$-четвёрmыx, сославшись на отсутствие доказательств использования морских формирований в прошлом, Суд определил их как непригодные для проживания. Однако связь между отсутствием сообщества и непригодностью образования не являет- 
Толстых В. Л. Территориальные споры в Восточной и Юго-Восточной Азии: особенности и перспективы международно-правового урегулирования

ся настолько жёсткой: люди могут игнорировать пригодные для проживания образования, если в их распоряжении имеются более удобные места; интерес может возникать постепенно, по мере демографического роста. Кроме того, в рассуждениях Суда есть серьёзный пробел: Суд заявил о том, что искусственное поднятие рифовой платформы не превращает дно в осыхающее при отливе возвышение, а последнее - в остров, но не стал рассматривать вопрос о том, может ли масштабное строительство сделать остров пригодным для проживания по смыслу ст. 121. В контексте дела это означало бы возможность квалификации некоторых образований ЮКМ как островов, с последующим допущением возможности их присвоения Китаем [4].

Реакция Китая на Решение была жёсткой и бескомпромиссной. Китайские власти заявили, что острова в ЮКМ и акватория Л9Ш принадлежат Китаю, который открыл, назвал и освоил их; Суд не обладал юрисдикцией по вынесению Решения; арбитражный процесс является «политическим фарсом». Китай также усилил свой флот в ЮКМ и заявил, что готов применить силу.

8. Отношение России к территориальным спорам в Южной и Юго-Восточной Азии не должно быть пассивным. Россия не имеет прямых интересов в конфликтах первой группы и одновременно поддерживает дружественные отношения с их участниками: Китаем, Индией и в меньшей степени Пакистаном. В этой связи она может попробовать вернуться к своей традиционной функции посредника в данном регионе. Успешная реализация этой функции позволит ей заручиться политической поддержкой данных государств в отношении её собственных интересов и, возможно, получить экономические преференции. Конфликты второй группы не затрагивают интересов России; по отношению к ним она, как представляется, должна соблюдать строгий нейтралитет. Что касается конфликтов третьей группы, то Россия сама является их непосредственным участником. Как результат, она должна предпринимать усилия, направленные на достижение выгодного для неё урегулирования вопроса о Курильских островах; одним из факторов успеха может быть выработка общей с Китаем и Кореей позиции по ряду вопросов, связанных с интерпретацией Сан-Францисского договора 1951 г. и других документов. Россия заняла сдержанную позицию по отношению к конфликту в Южно-Китайском море (четвёртая группа): МИД РФ заявил, что не будет занимать чью-либо сторону, но косвенно поддержал позицию Китая, указав, что «консультации и переговоры должны вестись непосредственно между вовлечёнными сторонами в определяемом ими самими формате» [3]. Возможно, прямая поддержка позиции КНР в большей степени соответствовала бы интересам РФ. Дело в том, что притязания Китая на суверенитет над островами ЮКМ содержательно близки притязаниям России на суверенитет над островами её полярного сектора, а притязания Китая на исторические права в ЮКМ - близки притязаниям России на исторические права в ВосточноСибирском море, Карском море и море Лаптевых; в обоих случаях основой претен- 
зий является длительное, мирное и исключительное использование. Поддержав позицию Китая, Россия подтвердила бы свои собственные титулы; неиспользование Россией этой возможности, наоборот, подрывает их.

\section{Список литературы}

1. Вылегжанин, А. Н. Российско-японские договоренности о морских районах, примыкающих к Южно-Курильским островам / А. Н. Вылегжанин, Е. В. Неверова // Московский журнал международного права. - 2016. - № 2. - С. 35-57.

2. Гаврилов, В. В. Южные Курильские острова: проблемы и перспективы определения правового статуса // Азиатско-Тихоокеанский регион: экономика, политика, право. - 2015. - № 2 (35). - С. 75-85.

3. Захарова, М. Позиция РФ по Южно-Китайскому морю неизменна. 14 июля 2016 г. - URL: https://russian.rt.com/article/312173-mariya-zaharova-poziciya-rf-poyuzhno-kitaiskomu (дата обращения: 31.12.2019).

4. Толстых, В. Л. Международный арбитраж против морского права (анализ решений по делам Arctic Sunrise, о Южно-Китайском море и спору между Хорватией и Словенией) // Московский журнал международного права. - 2019. - № 3. C. $128-140$.

5. Dolven, B. Maritime Territorial Disputes in East Asia: Issues for Congress / B. Dolven, S. Kan, M. E. Manyin ; Congressional Research Service, 2013. - URL: https:/www.researchgate.net/publication/292245161_Maritime_territorial_disputes_in_E ast_Asia_Issues_for_Congress (дата обращения: 31.12.2019).

6. Muni, S. D. Conflicts in South Asia: causes, consequence, prospects // India, Europe and conflict resolution in South Asia / ed. by R. K. Jain ; Institute of South Asian Studies / S. D. Muni. - New Delhi : KW Publishers Pvt Ltd, 2015. - URL: https://ru.scribd.com/book/311484157/India-Europe-and-Conflict-Resolution-in-SouthAsia (дата обращения: 31.12.2019).

7. Taylor, F. Territorial and maritime boundary disputes in Asia. - DOI 10.1093/oxfordhb/9780199916245.013.0027 // Oxford handbook of the international relations in Asia / ed. by S. M. Pekkanen, J. Ravenhill, R. Foot. - Oxford : Oxford University Press, 2014. - Chapter 7. - URL: https://www.oxfordhandbooks.com/view/10.1093/ oxfordhb/9780199916245.001.0001/oxfordhb-9780199916245-e-027\#oxfordhb-9780199916245e-027-div1-2 (дата обращения: 31.12.2019). - Режим доступа: по подписке.

\section{References}

1. Vylegzhanin A.N., Neverova E.V. Rossiisko-yaponskie dogovorennosti o morskikh raionakh, primykayushchikh k Yuzhno-Kuril'skim ostrovam [Russian-Japanese Agreements Relating to the Sea Areas Adjacent to the Disputed Southern Kuril Islands]. Moskovskii zhurnal mezhdunarodnogo prava, 2016, no. 2, pp. 35-57. 
2. Gavrilov V.V. Yuzhnye Kuril'skie ostrova: problemy i perspektivy opredeleniya pravovogo statusa [The Southern Kuril Islands: Problems and Prospects of the Legal Status]. Aziatsko-Tikhookeanskii region: Ekonomika. Politika. Pravo - Pacific RIM: Economics. Politics. Law, 2015, no. (35), pp. 75-85.

3. Zakharova M. Pozitsiya RF po Yuzhno-Kitaiskomu moryu neizmenna [The position of the Russian Federation on the South China Sea is unchanged, July 14, 2016]. Available at: https://russian.rt.com/article/312173-mariya-zaharova-poziciya-rf-poyuzhno-kitaiskomu (accessed 31 December 2019).

4. Tolstykh V.L. Mezhdunarodnyi arbitrazh protiv morskogo prava (analiz reshenii po delam Arctic Sunrise, o Yuzhno-Kitaiskom more i sporu mezhdu Khorvatiei i Sloveniei) [International Arbitration against the Law of the Sea (analysis of decisions on Arctic Sunrise, the South China Sea and the dispute between Croatia and Slovenia)]. Moskovskii zhurnal mezhdunarodnogo prava, 2019, no. 3, pp. 128-140.

5. Dolven B., Kan S., Manyin M.E. Maritime territorial disputes in East Asia: issues for Congress. Congressional Research Service, 2013. Available at: https://www.researchgate.net/publication/292245161_Maritime_territorial_disputes_in_E ast_Asia_Issues_for_Congress (accessed 31 December 2019).

6. Muni S.D. Conflicts in South Asia: causes, consequence, prospects. In: Jain R.K., ed. India, Europe and conflict resolution in South Asia. Institute of South Asian Studies. New Delhi: KW Publishers Pvt Ltd, 2015. Available at: https://ru.scribd.com/book/ 311484157/India-Europe-and-Conflict-Resolution-in-South-Asia (accessed 31 December 2019).

7. Taylor F. Territorial and maritime boundary disputes in Asia. In: Pekkanen S.M, Ravenhill J., Foot R., eds. Oxford handbook of the international relations in Asia. Oxford: Oxford University Press, 2014. Available at: https://www.oxfordhandbooks.com/ view/10.1093/oxfordhb/9780199916245.001.0001/oxfordhb-9780199916245-e027\#oxfordhb-9780199916245-e-027-div1-2 (accessed 31 December 2019). 